\title{
STYLES OF DECISION MAKING AND MANAGEMENT AND DIMENSIONS OF PERSONALITY OF SCHOOL PRINCIPALS
}

M.Sc Anita Azeska, PhD Candidate, MIT University, Faculty of Psychology, Skopje, Republic of Macedonia

E-mail: a.azeska@gmail.com

Dr. Jasmina Starc, Higher education centre Novo Mesto, Slovenia

E-mail: jasmina.starc@guest.arnes.si

Dr. Ljupco Kevereski, Faculty of Education, University “St. Kliment Ohridski”, Bitola, Republic of Macedonia

E-mail: kever@mt.net.mk

ARTICLE INFO

Original Research

Received: September, 27.2017.

Revised: December, 05.2017.

Accepted: December, 10.2017.

doi:10.5937/IJCRSEE1702047A

UDK

371:005.322(497.7)

Keywords:

styles of decision making,

management styles,

extraversion;

neuroticism; psychoticism,

workplace.

\begin{abstract}
A B S T R A C T
This paper explores preference to the style of decision making (managerial, analytical, conceptual and behavioural), (Alan Rowe, 1992), management styles (relationship-oriented leadership and management by objectives), (Fiedler, 1987) and personality traits (extraversion, neuroticism and psychoticism), (Eysenck, 1998). The convenience sample of 61 respondents (principals of primary and secondary schools from Macedonia) were subjected to decision making style inventory (Decision Style Inventory - DSI) of 20 claims, a questionnaire to assess the management style (Least preferred coworker - LPC) composed of 18 bipolar adjectives, and a personality test (Eysenck Personality Questionnaire - EPQ) composed of 90 items in the form of questions. Results show that schools lean towards directive style of decision making with a combination of democratic-participatory style that includes subordinates in the process of decision making. The results also demonstrate that school principals prefer management style motivated by relationships; they are more introverted and emotionally stable. The findings indicate a necessity for a new generation of managers who will be different from the traditional managers. It is evident that the future will require managers with leadership styles different from the traditional in Republic of Macedonia. Given that the school is a basic organisational cell on which the educational system of the country is based, the proposed findings present an occasion for developing new ideas and practices that may yield great results. This would increase the flexibility and adaptive capacity of the school as a modern organisation. Thus, these findings have practical implications as they may direct special training of principals in order to apply the best management style, or style that is most appropriate for certain situations, certainly through coordination of the desired profile of the principal and the business strategy, development and maturity of the organisation.
\end{abstract}

(C) 2017 IJCRSEE. All rights reserved.

\section{INTRODUCTION}

Leadership begins and ends with people; their aspirations, feelings, motivations and the way they communicate. Winston

Corresponding Author

M.Sc Anita Azeska, PhD Candidate, MIT University, Faculty of Psychology, Skopje, Republic of Macedonia E-mail: a.azeska@gmail.com

\section{c)}

This work is licensed under a Creative Commons Attribution - NonCommercial - NoDerivs 4.0. The article is published with Open Access at www.ijcrsee.com
Churchill characterised leadership as intelligent use of force (Anderson et al., 2001).

Rowe (Rowe et al., 1989) states that the future requires leaders who have a vision as well as ability to inspire others, and who can turn their vision into reality that way.

Making decisions is one of the main activities of a leader. Wren and Voich (Wren and Voich, 1994) believe that decision making is mandatory for successful execution of any managerial function. According to the Four Quadrant Model of the Brain of Ned Herman, Rowe (Rowe et al., 1989) defined four styles of decision making. The activity of each quadrant of the brain is the basis for 
a particular style of decision making. Rowe (1992) determined styles of decision making through combining cognitive complexity and value orientation. Cognitive complexity stems from the use of information to the conceptual ability of parallel information processing and generalisation, i.e. determining strategy. Value orientation is based on the orientation of technical values (tasks) to the orientation of organisational values (people). The styles of decision making that Alan Rowe talks about are the following:

- Directive - used by autocratic leaders who show tendency to behave aggressively. They make decisions on the basis of a relatively small amount of information and lack tolerance for vague information.

- Analytical - managers with analytical style in cognitive terms are complex. They make decisions by researching extensive data and have increased tolerance for vague information.

- Conceptual - is notable in managers with need for recognition and success. They make decisions based on extensive elaboration of data and tend to be creative and inventive.

- Behavioural - characterises managers with exaggerated need for acceptance (affiliation) and democratic relations with subordinates. They make decisions taking care to maintain good relations with other employees.

Early analyses of leadership, from 1900 to 1950 , defined the features of the relation between a leader and their followers. The findings that not a single feature or combination of features can explain leadership abilities in entirety has prompted many researchers to begin studying the impact of situation on leadership skills and behavior (Day and Antonakis, 2012).

Fiedler's contingency theory is an attempt to explain how the situation models the relation between the personality of the leader and effectiveness (Nikoloski, 2000). Fiedler attempted to predict leader effectiveness based on a personality trait called least preferred coworker (LPC). This theory covers two management styles - relationship-oriented leadership and management by objectives. Managers motivated by objectives are primarily focused on achieving goals, while managers motivated by interpersonal relations aim to develop close interpersonal relationships with subordinates. These two styles are analogous, perhaps even completely identical with the styles oriented towards people and work.

The preferred management style reveals various aspects of organisational behaviour, in which the variables of personality have great importance because they are one of the major conditions that affect the behaviour and the person determines behaviour in a defined situation as per Catell (Peck, 1978). Or, "leadership is largely a phenomenon that stems from the personality of a leader" - Čizmič (Čizmič, 1995 , p. 64). The discovery of the relation between management styles and personal traits enables strategic implementation of organisational goals, greater efficiency and higher performance (Yukl, 2010).

Eysenck defines personality as "a whole set of actual and possible forms of reaction of an organism determined by heredity and environment, and accrued and developed through interaction of four main areas: cognitive (intelligence), conative (character), affective (temperament) and somatic (constitution)" Eysenck (Eysenck, 1998 per Lojk, 1991). In his research and study of personality Eysenck (Eysenck, 1998 per Lojk, 1991), using a statistical technique factor analysis, extracted three basic dimensions or personality traits that he believed to be most important in addition to intelligence:

A) The trait extraversion (E) is a continuum whose ends are arranged in "clean", extreme forms of extraversion and introversion, which include fewest people because most people are closer to one or to the other end of this continuum. Each individual occupies a different position in the same continuum.

B) The trait neuroticism (N) is described by two extremes: emotional stability and emotional lability.

C) The trait psychoticism (P) is defined by two extremes: hardness, rigidity, intransigence, aggression, indifference of the person as opposed to a person that is indulgent, sensitive, empathic, cares for other people.

These traits are normally distributed in the general population, which means they are present in all humans in varying degrees and only the extreme forms of the continuum of normality represent pathological abnormalities.

The definition of the research problem and the postulation of the hypotheses in this study were determined by the: Theory of human nature, in particular the view of the complexity of human nature and its variability, Bojanović (Bojanović, 1988); Fiedler's contingency theory, which is an attempt to explain how the situation models the relation between the personality of the leader and effectiveness, Fiedler (Fiedler, 1978); Eysenck's theory of personality, which provides useful model for 
understanding individual behaviour and creation of verifiable predictions, Peck (Peck, 1978); Thus, there are three hypotheses:

1. School principals have more pronounced directive and conceptual style of decision making and less pronounced analytical and behavioural style of decision making.

2. School principals prefer relationshiporiented leadership and show lesser preference for task-oriented management (management by objectives).

3. In school, principals' extraversion is most notable as a trait, while psychoticism is the least notable.

\section{MATERIALS AND METHODS}

\subsection{Respondents}

The survey was conducted on a convenience sample of 61 respondents (principals of primary and secondary schools). According to the number of valid questionnaires for variable styles of decision making and personality types, the number of respondents is 58 principals of primary and secondary schools. According to the number of valid questionnaires for variable management styles, the number of respondents is 61 principals of primary and secondary schools.

\subsection{Measurement instruments}

The decision making style inventory (DSI) by the author Rowe consists of 20 claims that the respondent completes with 4 different statements concerning the 4 styles of decision making: managerial, analytical, conceptual and behavioural style. The respondent is required to rank the statements of every claim according to a 4 - degree correspondence scale of 1 (least correspondence) to 4 (most correspondence for the respondent - a manager). Data on the internal homogeneity of the applied measurement instrument obtained for the sample in this study show that the values of $\alpha$ - coefficients for the four styles of decision making are of low internal consistency.

The questionnaire "Least preferred coworker" (LPC) developed by Fiedler (Fiedler, 1984) was used in the study in order to assess management style.

The management style is determined by describing the least compatible coworker when it comes to performing tasks, i.e., the least-preferred coworker score is determined by asking the manager to remember all of their past and current associates, choose the one with whom they would not work well, and rate the associate on a scale that consists of 18 bipolar adjectives by selecting the corresponding number from 1 to 8 for each of the adjectives (e.g. friendly - hostile, cooperative - uncooperative, efficient - ineffective).

The final score is the sum of the ratings rounded up to 18 items. The lowest possible score is 18 and the highest possible score is 144. If the score is lower, it indicates that the individual is motivated by tasks, whereas a higher score on the scale indicates individuals motivated by relationships. The internal consistency, that is, the value of the $\alpha$-coefficient of the LPC scale, obtained on the sample in this study, is high.

The personality test (EPQ) consists of 90 items in the form of questions. The respondent responds by selecting one of the two offered alternatives - YES or NO - during an indefinite period of time. The total individual score for each scale is obtained by simply counting all selected YES and NO responses that measure the corresponding dimension using the appropriate scoring key for the answers. In the EPQ inventory, the traits neuroticism and extraversion as well as the L - scale have acceptable internal consistency, while psychoticism is of low internal consistency.

\subsection{Procedure}

Data collection took place in the period from January 2016 until May 2016, in the workplaces of the respondents.

\subsection{Statistical data processing}

Data are processed with the statistical program SPSS - 20 and the basic statistical indicators (arithmetic mean, standard deviation, highest and lowest score) are presented for all the used variables.

\section{RESULTS}

From the data presented in Table 1, it is evident that school principals favour the directive style, while the behavioural style is least pronounced. 
(IJCRSEE) International Journal of Cognitive Research in Science, Engineering and Education Vol. 5, No. 2, 2017.

Table 1. Basic statistical indicators for styles of decision making

\begin{tabular}{lccccc}
\hline \multicolumn{1}{c}{ Directive style } & $\mathbf{N}$ & $\mathbf{M}$ & SD & $\begin{array}{c}\text { Lowest } \\
\text { score }\end{array}$ & $\begin{array}{c}\text { Highest } \\
\text { score }\end{array}$ \\
\hline School principals & 58 & 58.55 & 6.41 & 36.00 & 74.00 \\
\hline Total & 58 & 58.55 & 6.41 & 36.00 & 74.00 \\
\hline Analytical style & & & & & \\
\hline School principals & 58 & 55.26 & 4.02 & 42.00 & 64.00 \\
\hline Total & 58 & 55.26 & 4.02 & 42.00 & 64.00 \\
\hline Conceptual style & & & & & \\
\hline School principals & 58 & 44.50 & 4.98 & 38.00 & 57.00 \\
\hline Total & 58 & 44.50 & 4.98 & 38.00 & 57.00 \\
\hline Behavioural style & & & & & \\
\hline School principals & 58 & 41.60 & 6.56 & 30.00 & 68.00 \\
\hline Total & 58 & 41.60 & 6.56 & 30.00 & 68.00 \\
\hline
\end{tabular}

From the data presented in Table 2, it is evident that school principals are more motivated to have close interpersonal relationships with other people in their work.

Table 2. Basic statistical indicators for management style

\begin{tabular}{lccccc}
\hline Management style & N & M & SD & $\begin{array}{c}\text { Lowest } \\
\text { score }\end{array}$ & $\begin{array}{c}\text { Highest } \\
\text { score }\end{array}$ \\
\hline School principals & 61 & 79.92 & 11.96 & 55.00 & 103.00 \\
\hline Total & 61 & 79.92 & 11.96 & 55.00 & 103.00 \\
\hline
\end{tabular}

From the data presented in Table 3, it is evident that school principals display more extraversion and neuroticism, while the psychoticism trait is less pronounced.

Table 3. Basic statistical indicators for extraversion, neuroticism and psychoticism

\begin{tabular}{lccccc}
\hline \multicolumn{1}{c}{ Extraversion } & N & M & SD & $\begin{array}{c}\text { Lowest } \\
\text { score }\end{array}$ & $\begin{array}{c}\text { Highest } \\
\text { score }\end{array}$ \\
\hline School principals & 58 & 12.72 & 2.67 & 4.00 & 18.00 \\
\hline Total & 58 & 12.72 & 2.67 & 4.00 & 18.00 \\
\hline Neuroticism & & & & & \\
\hline School principals & 58 & 9.59 & 3.68 & 3.00 & 19.00 \\
\hline Total & 58 & 9.59 & 3.68 & 3.00 & 19.00 \\
\hline Psychoticism & & & & & \\
\hline School principals & 58 & 9.52 & 0.96 & 7.00 & 11.00 \\
\hline Total & 58 & 9.52 & 0.96 & 7.00 & 11.00 \\
\hline L - honesty & & & & & \\
\hline School principals & 58 & 15.17 & 4.26 & 5.00 & 21.00 \\
\hline Total & 58 & 15.17 & 4.26 & 5.00 & 21.00 \\
\hline
\end{tabular}

\section{DISCUSSION (DISCOURSE)}

The basic constructs in this paper are styles of decision making, management styles, personality traits and workplace. Namely, on numerous occasions, referring to the results of the research that dealt with the issues of the aforementioned variables, it was emphasised that decision making is one of the most frequent and most important managerial activities and that leadership, among other things, is a projection of the personality of the manager, that is, leadership is a phenomenon that stems from the personality of the leader.

The definition of the research problem and the postulation of the hypotheses were guided by the: Theory of human nature, in particular the view of the complexity of human nature and its variability, Bojanović (Bojanović, 1988); Eysenck's theory of personality, which provides useful model for understanding individual behaviour and creation of verifiable predictions, Peck (Peck, 1978); Fiedler's contingency theory, which is an attempt to explain how the situation models the relation between the personality of the leader and effectiveness, Fiedler (Fiedler, 1978).

The results of the research showed that primary and secondary school principals have significantly pronounced directive style. The prominence of the directive style of school principals or dominance of this style in the application within these institutions suggests that they are more autocratically managed organisations. These managers make decisions quickly and prefer clearly defined rules and relations, order and security (Karavelioğlu, 2014). The descriptive statistics also show that the analytical style is present in levels above-average. Rowe (Rowe, 1992 according to McKenna, 2000) suggests that the analytic style is inherent for managers who value achievements and who display a certain tendency towards autocratic governance.

Starting from the findings of Burns and Stalker (1961 according to McKenna, 2000), the directive and somewhat analytical style are considered relevant to a bureaucratic (mechanical) structure that is organised on the basis of hierarchical relations of authority, vertical one-way communication in top - bottom direction in the organisation, and centralisation of decision making. Applying the analytical style suggests a certain tolerance managers have for insufficiently clear information as well as endeavour to make right and sound decisions for the organisation. The two prevailing styles emphasise the need for power and the achievements of the managers.

Rowe (1992, according to McKenna, 2000) also points out that the directive and analytical decision making style belong to the left hemisphere, which is responsible for logical thinking, analysis, serial information, speech management as well as abstract logical reasoning.

Descriptive indicators further point out that the conceptual and behavioural styles are less pronounced among principals of (primary and secondary) schools, partly confirming 
the first hypothesis. Given that these styles belong to the right hemisphere, intuition and creativity in making decisions are inevitable. Thus, these principals, in addition to directive style that indicates tendency for autocratic behaviour, nevertheless apply democraticparticipatory style that includes subordinates in decision making, in order to make better decisions influenced by intuition and creativity. In the role of auxiliary styles, they use the conceptual and behavioural styles of decision making. This finding mirrors Rowe's opinion (1992, according to McKenna, 2000) that the styles of decision making are never expressed in absolute pure form, so that when one of the styles is prominent this does not mean that there are no impurities from another style in combination.

The conclusion is that in schools there is a tendency towards directive decision making with a combination of a democratic-participatory style that includes subordinates in making decisions. According to the average expression, managerial decision making styles can be ranked starting from directive as the most pronounced to behavioural as the least pronounced style, which is in accordance with the ranks of percentage distribution of styles among the Yugoslavian (Serbian) managers - $85 \%$ directive, $81 \%$ analytical, $73 \%$ conceptual and $60 \%$ behavioural style, Maletić et al. (Maletić et al., 1994). These results are similar to the results obtained in Marković's research (Markovič, 2006) where the situation is as follows: the analytical style is prevalent, then the directive, conceptual and ultimately, the behavioural style. The only difference is in the reverse order between the analytical and the directive style. Research carried out about managers in Japan, according to Maletić et al. (Maletić et al., 1994), show that the prevalent style among Japanese managers is the conceptual, and then analytical, directive and behavioural, while the analytical style is distinct among US managers, then the conceptual, directive and behavioural style.

What appears significant, and serves as a bold conclusion, is that when it comes to the managers in Macedonia and the managers from the countries of the former $\mathrm{Yu}$ goslavia, the styles of one brain hemisphere are distinct and prevalent, seeing as both the directive and analytical style belong to this hemisphere. In Japanese and American managers, the conceptual and analytical style are most pronounced, and these belong to different brain hemispheres - the conceptual to the right, whereas the analytical style belongs to the left hemisphere. It is evident, even though it is a bold conclusion, that the managers from the more developed world, e.g. Japan and America, use the two hemispheres of the brain in the process of making decisions, unlike the Macedonian managers and the managers from the countries of former Yugoslavia, where the prominent styles stem from the same hemisphere. This interested Ned Herman (Ned Herman, 1996), who studied the dominance of a particular quadrant of the brain and, accordingly, the mental preferences of members of different nations. This certainly represents a wide area for further research.

In the second hypothesis, as expected, the school principals showed preference for a management style motivated by relationships, rather than motivated by objectives.

From the descriptive statistics on management styles, it is evident that school principals manifest significantly more pronounced tendency towards close interpersonal relations.

The obtained results from this research, in accordance with Fiedler's interpretation (Fiedler, 1978) that the LPC score is an indicator of the hierarchy of the motives of the manager, suggest that school principals are more motivated to have close interpersonal relationships with employees, whereas the attainment of their objectives is a secondary motive that will become important only if the primary motive for affiliation is already satisfied. These managers see their least preferred associate in a positive light, because their primary need is to maintain good relations with others, to get along, and their secondary needs are directed towards the objective. Similarly, Likert (Likert, 1961, according to Bojanović, 1988) states that: People-oriented managers do not give detailed instructions on how the work should be done, but instead offer only general instructions, starting from the assumption that the employees are responsible and capable of organising the work on their own. This can also be considered as a justified assumption in our research. In addition comes the research of Shawn (2009), which shows that there is a positive relation between all the factors of transformational leadership and all the factors of school culture, seeing as the transformational leader treats their employees as the greatest valuable of the organisation. Furthermore, this type of leader stimulates the employees intellectually, offers them a significant role in decision making and motivates them to pursue higher goals, not just objectives of immediate interest, and enables employees to give their 
best contribution to the organisation - Hunt, Osborn (Hunt, Osborn, 1995). In view of the fact that the role of a principal is considered essential for the successful implementation of educational goals, the demands of school leaders are constantly increasing, creating an unlimited number of challenges. Kahn and Katz (Kahn and Katz, 1978) believe that some managers are inclined towards one, and others to another management style, because the styles in question fit their personality traits. The orientation to objectives and people may be taken as two tasks performed by the manager; the most favorable circumstance is when the two tasks are undertaken by the same manager. In the same vein, Kahn and Katz argue that orientation to objectives and people is not only a reflection of the manager's personal attributes, but also reflects the characteristics of the organisation.

The contingency theory emphasises that leaders are not effective in all types of situations. It is also very important that when considering the concept of leadership, the situation in the organisation should be taken into account. This theory provides information about the type of leadership that is highly likely to be effective in a particular context. By obtaining the LPC scale score and describing the three situational variables, the likelihood of one individual's success in a particular situation can be determined. The data obtained from the LPC scale can also serve in development of a leadership profile, and can be used along with other data in human resource planning in order to develop the profile of the individual and the best way they can fit into the organisation.

A research by Ahmad, Wagar and Khan (M. Ahmad; S. Wagar; R. M. Khan, 2010) suggests that the management style should have a direct impact on the level of organisational commitment of the employees and is moderated by the characteristics of the employees as well as environmental factors. Efficiency here depends on the way managers manage to balance the demands of the objective and the relations between employees.

According to Bojanović (Bojanović, 1988) the efficiency of the work depends on the motivation of the employees and their abilities. Sometimes the nature of the work requires authoritative management style due to the motivation type of the employees and their personality traits. Considering the fact that many features of the human nature change throughout life, the way of making decisions in the work, that is, the management style should present a challenge to those characteristics of a person that are susceptible to change.

The findings about the personality traits - extraversion, neuroticism and psychoticism - among school principals will be discussed in continuation.

Psychologists have always been aware of the meaning of the description of the main forms of human behaviour. The review of Eysenck's book (Lojk, 1991) confirms the aspect, which recognises the existence of two clear and very important traits. These are extraversion - introversion and neuroticism, or emotional balance - imbalance. Even though Eysenck does not want to deny the existence and meaning of other personality factors, he is convinced that $\mathrm{E}$ and $\mathrm{N}$ contribute more to personality description than any other combination of factors outside the cognitive domain.

In accordance with the hypothetical framework of this research, it was assumed that the school principals predominantly displayed extraversion as a trait, whereas psychoticism was the least expressed of the traits among them. Descriptive statistics support this assumption, thus confirming the hypothesis.

Extraversion, as the prefix suggests, has no relevance to the categorical distribution, but as previously mentioned, represents a continuum whose ends hold the "pure", extreme forms of extraversion and introversion, which include the smallest number of people, taking into consideration that most people approach one or the other end of this continuum. Each individual takes up a different position in the same continuum. According to the results of this research, it follows that bank presidents are more extraverted than school principals, or friendlier, more communicative, socially more expansive, easily adaptable. They are less fond of individualistic activities, preferring changes, and they are more initiative, adventurous, and optimistic compared to school principals.

In terms of prominence of neuroticism as a trait, arithmetic means show that school principals are emotionally stable. They are balanced and their emotional reactions are slower and milder.

Studies have confirmed that neuroticism is closely related to the hereditary degree of lability of the autonomic nervous system, while extraversion is dependent on the degree of prevalence of the excitation phase, i.e. inhibition of the central nervous system. This balance is probably genetically determined and related to the ascending pathways of the reticular formation.

The influence of the inheritance of ex- 
traversion and neuroticism has often been the subject of research of various authors, and perhaps the clearest evidence for this is the Shields survey from 1962 (Lojk, 1991), which discovered that there is high correlation of both extraversion and introversion found in monozygotic twins who were reared separately. Generally, it can be concluded that many stakeholders speak in favour of the view that legacy still has a very important role in the development of all three personality traits: extraversion, neuroticism and psychoticism. It seems that when it comes to individual differences, genetic factors play a greater role than the environment.

Personality development according to Eysenck is a result of interaction of genetic predispositions, the basis of which are the structure and functionality of the nervous system and the external environment in which a person develops. Taking into account that the nervous system of different organisms possess differing properties, different persons establish dissimilar relations with the same environment. In this way, the same objective environment participates in creating differences between people in terms of personality traits. Considering the varying genetic basis of the introverted and extraverted persons, socialisation as the most important way to personality development would be successful on different levels; an extraverted predisposition will often be countered by existing norms, unlike the introverted disposition.

It should be pointed out that Eysenck does not overemphasise the genetic conditionality of a person in terms of environmental factors, but himself claims that whether the extraverted disposition will become a personality type depends on the environment. The autocratic way of educating children is a more convenient method for the socialisation of extraverted types of individuals than for the introverted types of individuals.

Considering that the EPQ questionnaire has been used for a long time, and Eysenck himself has devoted considerable time to its creation through factor analysis as well as auditing it, the instrument should be trusted. What is favourable is the fact that in the main review of existing factor analytic studies of personality, suggests the existence of three main factors, which are very similar to the factors measured by EPQ (Lojk, 1991). This confirms that the choice of the three factors is neither superficial nor subjective, but rather the result of an experimental record. In addition, according to Pek (Peck, 1978), Eysenck's theory is practical for creating verifiable predictions and presents a useful model for the differences between groups of individuals. However, Pek suggests that more attention should be paid to other factors, above all to social learning and cognitive factors.

On that account, according to the results of this research, the conclusion is that school principals prefer a management style motivated by relationships; they are more introverted and emotionally stable. School principals lean towards directive style of decision making with a combination of democratic-participatory style that includes subordinates in the process of decision making.

Observing the results of this study, the discussion is further elaborated upon with the findings presented in the Gino, Grant and Hofmann study (Gino, Grant and Hofmann, 2010). Based on previously conducted research, the authors state that the success of the leader depends on the members of the team when it comes to choosing between an introverted or extraverted person. In fact, when team members possess a lot of knowledge, the introverted leader is far superior to the extraverted leader, who, as a rule, diminishes the success of such a team due to their own desire for domination. In a situation of this type, a moderate, mild and non-directive management style, which introverted people normally possess, gives significantly better results compared to the directive style.

Unlike introverts, extraverted individuals are more dominant and aim to have the final word. Because of this, extroverts are not particularly good listeners and tend to assume the ideas of other people. Their inclination to impose their own solutions only presents an advantage when managing people who need to be told what they need to do, but not in the case of managing a professional team.

It can be said that integrity (possession of strong moral principles) is characteristic of introverts who are prepared to distance themselves from others and remain alone against everyone if their moral principles and their personal dignity are threatened. It is harder for extroverts to do the same, because they are constantly looking for company and they are emotionally dependent on other people to an extent.

The position head of company carries with it a burden of loneliness that introverts are able to tolerate more easily compared to extroverts.

Although at first glance, according to Gino, Grant and Hofmann (Gino, Grant and 
Hofmann, 2010), extroverts seem destined to become successful leaders, experience shows differently in many cases. The best examples of introverts becoming successful leaders are Bill Gates, the founder of Microsoft and Jeff Bezos, the founder of Amazon.

Some new studies warn that the work system that does not recognise the value of introverts experiences a loss when they fail to promote them to higher positions. Due to the stereotypical representations of leaders, the general view is that the leader is an extraverted, assertive and dominant person. Not only that, but also that the majority of decisions in the process of selecting managers is based on big ego and personal ambitions of one such person. It is not unusual to comment in professional circles that someone is not capable of being a manager because they are too modest, withdrawn and insufficiently fierce.

This attitude is not uncommon in Macedonia and in the countries of former Yugoslavia, taking into account the results of studies which show that aggressive styles are more desirable in this region compared to other countries, as discussed above.

Even though decisions made by employers should be impartial and free from the influence of their personal value system, this is not the case in practice. In fact, decisions about hiring or promotion in good part are determined not only by the personal value system of the decision-maker, but also are a reflection of the organisational culture, and indirectly, the national culture.

Thus, the results of a 2009 study by researchers at the University of Minnesota, according to Gino, Grant and Hofmann (Gino, Grant and Hofmann, 2010), speak of the fact that extraverted individuals climb the hierarchical constellation more easily because extraversion is more desirable than introversion in the Western culture. In fact, out of all the executives who were included in the study, as many as $60 \%$ of them were singularly extraverted.

Introverts have leadership qualities as well, though they are not obvious at first glance. In actuality, introverted individuals are generally receptive to different ideas; they listen carefully, give preference to deeper conversations rather than small talk, and are particularly aware of how others perceive them and what others expect from them.

Researchers who explore this area according to Gino, Grant and Hofmann (Gino, Grant and Hofmann, 2010) advise that it is crucial for introverted people to fight for vis- ibility when it comes to their personal qualities and work, so that others would not benefit unfairly from their contribution. Introverts have numerous qualities that are significant for leadership positions, especially nowadays, considering the increasing tendency towards the fifth level of leadership (Level 5 Leadership: The Triumph of Humility and Fierce Resolve; Good to Great: Why Some Companies Make The Leap and Others Don't by Jim Collins). Introverts are more suited to this type of leadership than extroverts. Namely, according to Gino, Grant and Hofmann (Gino, Grant and Hofmann, 2010), the qualities of this type of leader are modesty, mildness, calm determination, highly developed self-awareness and self-control, and patience. That is, as people say - "Still waters run deep".

\section{CONCLUSION}

The culture, beliefs and value system in Republic of Macedonia as well as the specificity of the current state of the country influence the decision making process. The findings indicate a necessity for a new generation of managers who will be different from the traditional managers. It is evident that the future will require managers with leadership styles different from the traditional in Republic of Macedonia (Azeska, 2015).

Managerial education and training, coupled with organisation and other measures, would diminish the extreme characteristics of autocratic leadership and would contribute to strengthening the leadership that would be equally oriented towards both objectives and interpersonal relationships, which would be much more convenient for the current as well as the coming times. In fact, accepting and integrating possible leadership styles would result in the best opportunities for success. For a successful appearance and persistence in the processes of globalisation, the necessity for permanent and organised managerial education is implicit (Azeska, 2015).

The conclusion is that this research contributes to the expanding of empirical knowledge in the area of decision making within the school as fundamental organisational cell on which the educational system of the country is based.

\section{Conflict of interests}

The authors declare no conflict of interest. 


\section{ACKNOWLEDGMENTS}

The authors would like to express their gratitude to the school principals of primary and secondary school in the Republic of Macedonia for the assistance that made this research possible. Thanks are also due to all the participants who supported this research technically as teachers, professors and other employees in the schools.

\section{REFERENCES}

Azeska, A. (2015). Decision - making styles and management and personality dimensions of school principals and bank managers: Unpublished master thesis Skopje: Faculty of Philosophy

Anderson, N. Ones. S. D. Sinangil, K. H. \& Viswesvaran, C. (2001). Handbook of Industrial, Work and organizational Psyhology (vol.1): Personnel Psyhology. London: Sage Publications http://nyt-om-arbejdsliv.dk/images/pdf/2002/ nr4/ta02-4-95.pdf

Bass, M. B. (1990). Bass and Stogdill's handbook of leadership: New York, Free Press https://pdfs.semanticscholar.org/410a/ a20c1438c750464ccfa0312b5718f4475e30.pdf

Bojanovič, R. (1988). Psychology of Interpersonal Relationships. Belgrade: Naučna Knjiga

Čizmič S., Bojanovič R., Stajnberger i., Petrovič I. (1975). Psychology and Management, Belgrade: Faculty of Philosophy, Institute of Psychology.

Cizmič S. editor (1995). Psychology and Management, Belgrade: Faculty of Philosophy, Institute of Psychology.

Corr, P. J., \& Matthews, G. (Eds.). (2009). The Cambridge handbook of personality psychology (pp. 748-763). New York: Cambridge University Press. https://pdfs.semanticscholar.org/f884/5d5 9a2324233689dce4634f3b69bf947bfa6.pdf

Day, D. V., \& Antonakis, j. (Eds). (2012): The nature of leadership, $2^{\text {nd }}$ Edition. Thousand Oaks: Sage Piblications

Drenth, P. J. D., Thierry, H., Wolff, C.J. (1998). Handbook of work and organizational psychology. Psychology Press (Second Edition)

Eysenck, H. J. (1998). Dimension of Personality. New Jersey: Transaction Publishers.

Eysenck, H. J. (1950). Dimensions of personality (Vol. 5). Transaction Publishers. https://goo.gl/ UcydiY

Fiedler, F. E. (1978). The contingency model and the dynamics of the leadership process. Advances in experimental social psychology, 11, 59-112. https://doi.org/10.1016/S0065-2601(08)600052

Fiedler, F. E. (1987). New approaches to effective leadership, New York (John Wiley \& Sons, Inc)

Gino, F; Grant M. A and Hofmann A. D. (2010). "The Hidden Advantages of Quiet Bosses": Harvard Business Review http://www.hbs.edu/faculty/ Pages/item.aspx?num $=39233$

Herrmann, N. (1996). The whole brain business book: Unblocking the power of whole brain thinking in organizations and individuals. New York, San Francisco, Washington DC, Auckland, Bogota,
Caracs, Lisbon, London, Madrid, Mexico City, Milan, Montreal, New Delhi, San Juan, Singapore, Sydney, Tokyo, Toronto: McGraw-Hill, 6-19.

Hunt, J., Osborn, R., Schermerhofh, J. (1995). Transformational Leadership. Organizational Behavior

Јанаков, Б. (1997). Contemporary Theories of Personality. Skopje: Ein - Sof

Karavelioğlu, A. M. (2014). Analysis of Leadership Styles in Banking Sector in North Cyprus: Testing Factors Effecting Authoritarian Style and a Model for Banking Sector in a Small Island Economy. International Journal of Regional Development, 1(1), 39. https://doi.org/10.5296/ ijrd.v1i1.6513

Katz, D.\& Kahn, RL. (1978). The Social Psychology of Organizations $\left(2^{\text {nd }}\right.$ ed.). New York: John Wiley https://pdfs.semanticscholar.org/85f7/dadae6fc51905bd314871b7458cf0f5bade1.pdf

Likert, R. (1961). New Patterns in Management. New York: McGraw-Hill Book Co.

Lojk, L. (1991). EPQ - Eysenck's Personality Questionnaire (manual). Ljubljana: Institute for Labour Productivity of Ljubljana, center for psychodynamic resources.

M. Ahmad; S. Wagar; R. M. Khan, (2010). Leadership Styles and Organizational Commitment in Banks. http://cgr.umt.edu.pk/icobm2013/index. html

Maletić, J. Duđak Lj., Vukić B., (1994). Determining Decision Making Styles, XXI Yugoslav Symposium for Operational Research: Proceedings, SYM-OP-IS-94.

Markovič, Z. (2006). Profile of the CEO and management and decision making style preference. Doctoral thesis. Niś: Faculty of Philosophy

McKenna, E. (2000). Business Psychology and Organizational Behavior. A Student's Handbook. Third Edition. Psychology Press. https://goo.gl/ D8LcrS

Moorhead, G. And Griffin, W. R. (2001). Organizational Behaviour - Managing People and Organizations. New York: Houghton Miffin Company

Moorehead, G., \& Griffin, R. W. (2010). Organizational behavior: Managing people and organizations. South-Western/Cengage Learning.

Millon, T., Lerner, M.J., Weiner, I.B. (2003), Handbook of Psychology: Personality and Social Psychology (Tom V). Hoboken, New Jersey: John Wiley \& Sons, Inc http://www.communicationcache. com/uploads/1/0/8/8/10887248/handbook_of psychology volume 5 personality and social_psychology_2003.pdf

Mujtaba, B. G., \& Alsua, C. J. (2011). Task and relationship orientation of Americans: a study of gender, age, and work experience. Journal of Behavioral Studies in Business, 3(1). https://www.researchgate.net/profile/Dr Mu$\mathrm{jtaba} /$ publication/242748511 Task and relationship orientation of Āmericans a study of gender age and work experience// links $/ \overline{5} 4 \mathrm{ff} 290 \mathrm{~b} 0 \mathrm{cf} \overline{2} \mathrm{eaf} 2 \overline{1} 0 \mathrm{~b} \overline{\mathrm{b}} 83 \mathrm{c} . \overline{\mathrm{pdf}}$

M. Ahmad; S. Warap; R. M. Khan, (2010). Leadership Styles and Organizational Commitment in Banks. http://cgr.umt.edu.pk/icobm2013/index. html

Nikoloski, T. (2000). The Psychology of Labor. Skopje: Faculty of Philosophy

Pek, D. (1978). Theories of Personality: Belgrade, No- 
(IJCRSEE) International Journal of Cognitive Research in Science, Engineering and Education Vol. 5, No. 2, 2017.

lit

Rowe, A. J. (1992). Managerial Decision Making. New York: Macmillan Publishing Company.

Rowe, A.; Mason, O.; Dickel, K.; Snyder, N. (1989). Strategic Management - A Methodological Approach. New York: Addison - Wesley Publishing Company

Shawn, M.T. (2009). Relationship Between the Leadership Styles of Principals and School Culture: Electronic Theses \& Dissertations. https://digitalcommons.georgiasouthern.edu/cgi/viewcontent.cgi?referer=https://scholar.google.com/\&ht tpsredir $=1 \&$ article $=1269 \&$ context $=$ etd

Wren, A. D. \& Voich, J. R. Dan (1994). Management, process, structure and behavior. Belgrade: Privredni pregled

Yukl, G. (2010). Leadership in Organizations, $7^{\text {th }}$ ed. New Jersey: Prentice Hall. 